\title{
Perspectives on the challenges of leadership in schools to improve student learning systems
}

\author{
Ali Taufik, Zen Istiarsono \\ Teaching and Training Education Faculty,University of Kutai Kartanegara, Indonesia
}

\begin{tabular}{|c|c|}
\hline Article Info & ABSTRACT \\
\hline & \multirow{9}{*}{$\begin{array}{l}\text { This study is an analysis of the challenges of leaders in schools to improve } \\
\text { learning systems, trying to do an analysis of the six aspects of analysis during } \\
\text { the study. The main contribution of this research is related to how to deal } \\
\text { with challenges in improving learning systems in schools that have so far } \\
\text { faced challenges and obstacles, and these need to be analyzed and solutions. } \\
\text { This study uses a qualitative method with a case study model, because this } \\
\text { researcher is a case that must be disclosed and found a solution, looking at } \\
\text { the gap between quality, performance and leadership in several schools that } \\
\text { are the object of research and this research lasted for several years. four } \\
\text { months (18 weeks), the time is indeed quite short, but researchers try to use } \\
\text { this time effectively to produce something useful. In this case involving eight } \\
\text { school leaders, as participants, the results of the application of the six aspects } \\
\text { of indicators were able to improve teacher performance and from changes in } \\
\text { the learning system as well. can be significantly improved as evidenced by } \\
\text { the results of evaluating student learning, this research does indeed need to } \\
\text { be deepened comprehensively. The author measures the success rate of these } \\
\text { indicators by using a cluster system (individually intervening) individually } \\
\text { either for the principal or when assessing students, so the writer can see } \\
\text { the improvement. }\end{array}$} \\
\hline Received Jan 20, 2020 & \\
\hline Revised May 25, 2020 & \\
\hline Accepted Jul 22, 2020 & \\
\hline Keywords: & \\
\hline Leadership & \\
\hline Learning system & \\
\hline Management & \\
\hline Student & \\
\hline
\end{tabular}

This is an open access article under the CC BY-SA license.

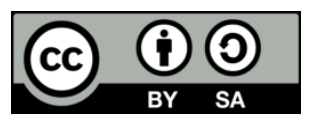

Corresponding Author:

Ali Taufik,

Teaching and Training Education Faculty,

University of Kutai Kartanegara,

Tenggarong, Kalimantan Timur, Indonesia.

Email: alfiforever@gmail.com

\section{INTRODUCTION}

The background of this research is about the challenges faced by leaders in schools. The aspect that must be followed up for future research, in this case is an increase in the principal's insight, because it will affect positively on the teacher, which in turn can increase student learning achievement.to improve learning systems, because the case in the field that researchers met during interviews with 8 school leaders who experienced challenges and difficulties in improving the learning system, this certainly many things that are related and need to be analyzed comprehensively, in order to find a solution In the characteristics of leadership management in general, there are two important things that must be owned by a leader (including school leaders), is a leader who has a leadership style. Transformational and transactional styles by applying leadership style transformational, then a leader will protect, provide knowledge/experience to staff/subordinates, so that with the application of transformational management patterns, the level of skills/intelligence of subordinates/staff (teachers in schools) is evenly distributed and finally has a work spirit (because they master the work) [1]. 
Furthermore, a wise leader will give rewards to employees (teachers at school), who have work performance, and then have a positive impact on teacher work performance, so that this will be able to improve student learning achievement at school, if this works then the system 'Learning' at the school is going well. Leadership with transformational and transactional models is indeed needed in growing the life and work ethic of employees/teachers or lecturers. According from Aarons [2], Leadership in organizations is important in shaping worker perceptions, responses to organizational changes, and acceptance of innovation, such as practice or evidence based.

Transformational leadership inspires and motivates staff, while transactional leadership is based more on reinforcement and exchange (rewards for objects) Leadership is very closely related to the success of learning in school institutions so that the role of school leaders, teachers becomes a central point in this research because school leadership and teachers must be able to provide new innovations in the learning system and also related to the curriculum of government programs, so that the role of teachers as conveyors of knowledge information also very decisive. According to Hoy [3] that the teacher is a maker of learning programs, then must also know student behavior, manage learning, time, then record the success/failure of students, then evaluate what needs to be done next (Woolkfolk's opinion, this actually not only for teachers, but also still very relevant for universities, because between teachers and lecturers only differ (where to teach and who is the subject). According to Vecaldo [4] in shaping leadership and major innovations in the education curriculum, teachers offer professional education offerings that shape leadership skills.

Teachers also have an important role in the development of learning systems, between leaders and teachers in order to create a synergy of performance systems. According to Nir [5], teachers tend to show a high commitment to student achievement, especially if they see the difference between achievement and increase the potential for professional prestige them, and give symbolic awards to children and parents as well as school principals/government leaders. To improve teacher learning systems must be able to generate "motivation" for students to learn, as Bigg's said [6], there are four motivations that need to be raised in students in an effort to improve, learning systems, including: instrument. motivation, social motivation, motivation achievement and intrinsic motivation. So, the four motivations must be raised first, to make changes to the learning system in the classroom. The development of the learning system is also very necessary, for example by providing training to school leaders, teachers and students, because the modern world learning system cannot regardless of the progress of IT, as Peter argues. With the advancement of e-learning, managers of educational institutions begin to deal with different activities, requiring the development of new procedures and finding alternatives to overcome emerging challenges that go beyond educational problems [7].

There are several opinions in terms of leadership and management in schools as a basis for concepts in. According to Barret and Breyer [8], leaders must instill enthusiasm in the soul of the teacher and provide effective leadership to motivate teachers then to provide energy (motivation) to students. Based on Wiezorek and Manard [9], school leaders work to balance their professional and personal lives and are challenged to meet the expectations of their communities to be seen and involved. To meet limited budget conditions, school leaders also maintain responsibilities by building infrastructure, etc., overlapping responsibilities. School leaders should focus on developing relationships and trust among teachers, students and their parents, for development of learning in schools they lead.

School leaders in receiving guidance from school supervisors, to improve leadership competence in schools. According to Lowery [10], the benefits of learning general leadership skills apply to supporting school counselors. School principals must be prepared to work with school counselors, in the opinion of the above school leaders are also ready to work with school supervisors to improve competencies and learning systems in school institutions and more and more leaders who focus their relationships, their work, and core learning and the greater the effect on student achievement [11]. The leader is essentially a subordinate, they must serve. According to Terosky and Reitano [12], the leader works for the progress of their followers while trying to achieve goals for the organization. Then, they are required to work for the greater good than those they serve. Leaders should have ethical and moral qualities that enable them to serve as examples for followers in an organization, including school institutions.

Actually, the core problem in leadership and management in schools in several countries including Indonesia is the same case. According to [13], government policies that are considered failing, and then involve the responsibilities of school leaders, school management does not work well, lack of community participation (students' parents), and lack of government funding, while targets must be achieved, because of responsibility to students and the community, and this is a challenge for school leaders to improve the learning system in schools, given that it is a national interest that must be done. Leadership, for an organization is needed, a leader who is able to become a manager. According to [14], training and 
development in school management and leadership, is very important together with practicing leadership in schools, so the experience of contributing to a career as a school leader must starting from being a teacher.

Dina [15] said that educational leadership is mainly related to the duties and responsibilities of the leadership team to improve school management, as well as student achievement, to increase the sense of responsibility of school leadership, then the people responsible for school administration, consisting of the principal and teacher. According to [16], the principal must create a comfortable school environment, a safe and pleasant work environment that pleases teachers and employees who can carry out their duties and work responsibly.

Recruitment teacher also needs to be chosen properly so that those who pass the exam to become teachers are truly dependable people. Proven is the main impetus for early teacher education courses to have a measurable impact on classroom practices in the future, to improve student learning outcomes at school [17]. By attending training on leadership, learning systems, etc., for the progress of the school and students in the school. The teacher as a driving force in student learning in class is very important in the development of learning systems, because the teacher's task is the closest object to students. According to Whittle [18], exploring students' perceptions can provide valuable insights about factors related to teacher whose students are in the stage of increasing learning achievement and ultimately influencing students' academic achievement (the teacher plays a role in the development of learning). Teachers who are given assignments according to their educational background, will be more proficient in the fields taught, than teachers who only get short courses. The importance of conformity between teacher education and the teaching context and the influence of school norms on teacher change, as an introduction to thinking for class management [19].

Teachers improve in the development of knowledge it must be done because the teacher is one source of information from students, the development of learning systems. According Ho and Lee [20], the challenging context that needs to be addressed is professional qualifications and teacher education, at least resulting in the development of a procession, so that learning becomes professional so there are no obstacles for students entering higher education (universities). According to previous research [21], motivation is very important to do in an effort to improve morale in work and study, so the role of leaders and teachers is very important.

School leaders must also be wise with teachers and other staff, because some leadership attitudes that are authoritarian and tend to behave like kings, will affect the performance of teachers or other staff, and this will have a negative impact on teacher responsibilities, which in turn will have an impact on the learning system in the classroom. According to Mullen and Jones [22], if the primary educational goal of progressive schools is to create and maintain more democratic schools by enabling the growth of teachers as responsible leaders to become more professional, then they must be given the opportunity to develop as leaders who are democratically responsible, in the classroom that is the responsibility of the teacher. According to Bush and Glover [23], the importance of leadership in schools that have been developed into leadership theory and this is very useful for teachers and school principals, and leadership changes are most effective with discussions about forms of learning between principals and teachers [24]. In accordance with the role of school leadership, is the center of attention about change and organizational development going forward [25]. In ethics controlling school leadership, showing teacher leadership and participation is very important in supporting an institution [26]. Each school principal has a significant responsibility for the results of student achievement, because leadership greatly influences teacher performance [27] and that if the power in the education system is delegated to the principal, the principal must take responsibility for the achievement [28].

Research on leadership has done it a lot, with a variety of methods/findings and models, but in this study researchers tried to describe some of the results of the analysis in the form of indicators, so that it is easier to understand and apply in the learning system, and also the research is not only focused on leadership, but how can a leader be able to overcome the problems faced as a leader, researchers here try to offer concepts in leadership, especially leaders in schools and related systems.

In this study, there are three questions about the challenges in leadership to improve learning systems in schools: 1) What are the challenges faced by school leaders? 2) How to overcome challenges or obstacles Then 3) Why must periodically evaluate these challenges and obstacles? This study aims to find solutions to minimize the challenges/obstacles faced by a leader in the school in an effort to improve the learning system in schools, and the benefits of this research to contribute thoughts (research results), to improve the learning system, which must start from school leadership, then the teacher as the executor in the class. 


\section{RESEARCH AND METHODS}

\subsection{Research design}

In understanding the problems that occur comprehensively within the scope of very complex human activities, the authors use a qualitative approach with a case study model, because the researcher considers, this study cases/problems that need to be revealed and solutions sought. Qualitative research according to Creswell [29], qualitative research: as "a process of understanding inquiry based on the tradition of different inquiry methodologies that explore social or human problems" [29]. In this study, there were eight school leaders who participated, as informants to be interviewed, from the school that was used as the object and place of research, the time of the study was around four months (18 weeks).

\subsection{Participants, instrument and data analysis}

After making observations, then conducting interviews with participants, distributing questionnaires with limited questions (purposive sampling) to six participants who the researchers considered fulfilled the criteria as informants, then collected data documentation, using analytic data collection techniques and data collection, according from [30] using three stages, namely (a) data reduction, (b) display data, and (c) draw conclusions from data analysis, namely the process of analyzing data collection in the field, in accordance with the formulation of the problem, then also proven by the results of data processing in narrative form. Comments from the informant (data display in the process of becoming narrative comments).

In this research, the researcher asked the participants questions, namely one question: How do you overcome the challenges in developing a learning system in your school? The answers from the participants will be seen, what and how and what the results will be. This question is only one, because the author wants to know, the level of depth of each participant in overcoming challenges or obstacles, in the development of learning systems in the schools they lead. After the data is processed according to qualitative research procedures, the researcher validates the data to prove the level of accuracy/validity of the data by using a four-level criteria model, according ,Yin [31], (a) Build Validity, (b) Internal validity, (c) External validity, (d) Reliability.

\section{RESULT AND DISCUSSION}

\subsection{Model of leadership and coordination in the field}

From the results of the research data, there are five aspects that must be present in each of choosing a leader or principal, so that the principal who is appointed, will be able to work, is responsible for his work here are the five aspects, shown in Figure 1.

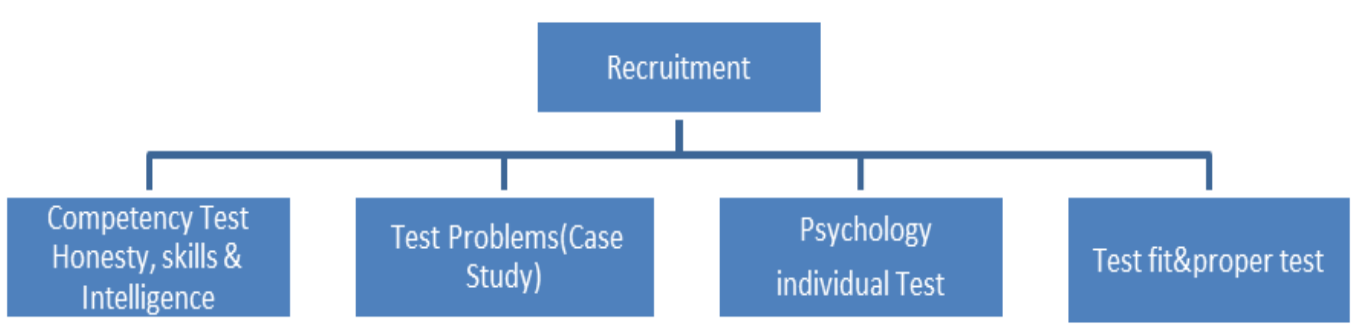

Figure 1. Five aspect leadership test coordination field

To answer the three research analysis questions related to the purpose of this study "The Challenge of Leadership in Schools to Improve Learning Systems", and from the results of data analysis, interviews and questionnaire answers to questions to participants, then produces six aspects of the indicators of the results of research analysis that must be done school leader. Six aspects of the results of the research analysis: Cooperation, Coordination, Investigation, Analysis, Implementation, and Evaluation.

a. Cooperation: School leaders must be able to foster cooperation with teachers as partners in this school the most principle in building the development of learning systems in schools.

b. Coordination: School leaders must coordinate with the teacher as the closest partner in finding solutions if there are obstacles encountered in the development of learning systems in schools.

c. Investigation: School leaders and teachers must investigate what problems are obstacles in implementing the development of learning systems in schools. 
d. Analaysis: School leaders and teachers must do an analysis of the main problems that become obstacles in developing learning systems in their schools.

e. Implementation: School leaders and teachers must implement the results of the analysis to become a standard in the development of learning systems in their schools.

f. Evaluation: School leaders and teachers must evaluate the concept of learning development, when formative/summative/evaluation, if there are weaknesses, make improvements.

Those are the six aspects that must be done in developing a learning system in schools and the need for collaboration between school leaders and teachers as the closest working partners in schools.

School leaders with transformational and transactional zeal as policy makers in schools immediately take steps to coordinate with teachers, to reform the learning system by adjusting the curriculum as a reference guide School leaders must also give time to teachers to improve their skills/human resources in matters that are relating to the improvement of learning systems, for example: provide opportunities for teachers to learn to explore IT/computers/other similar media, because this is important for the development of learning resources today, it is difficult for teachers who still do not/do not understand the development of learning technology, in the application of increasingly modern learning systems. Provide opportunities for teachers who have a creative enthusiasm related to the learning system, to develop their talents (motivation). Provide opportunities for teachers to speak outside formal meetings, related to the development of learning, in turn (alternately)/interview individually.

Then, what are the challenges/obstacles in developing learning systems in schools, in general the challenges or obstacles in developing learning systems in schools are not too different for example:

a. Challege/Obstacles in General: Poor management of school organizations, The pattern of leadership is lacking/does not work in accordance with the rules of the institution.

b. Inharmonious working relations between school leaders and other teachers/staff.

c. Openess of school leaders in managing the financial system. The lack of education supporting facilities/infrastructure

d. Challenges/Obstacles Specifically: Leaders who lack/do not master the job duties.

e. Leaders/teachers who experience personal problems, carried over in formal assignments. Leaders lack/do not have the authority/charismatic, in front of the teacher/staff. Leaders/Teacher competence is not yet/inadequate in several aspects of technology development

f. The relationship between school leaders and policy makers (supervisor control) is not harmonious.

Complete the research data, researchers also included interviews with six informants (their status were school leaders), in accordance with the agreement between researchers and informants, only using the initials of names in accordance with the informant's code of ethics:

Name of Informant: GR, Age: 45 years old, Occupation: School leader (Question: How do you overcome challenges in developing a learning system at school? Answer: If there are obstacles or challenges in developing the learning system, me and the teachers in the school immediately hold a meeting and coordinate as soon as possible to find out what causes it! (Interview from Informant I).

Name of Informant: DS, Age: 51 years old, Occupation: School leader (Question: How do you overcome challenges in developing a learning system in your school? Answer: We will evaluate the results of low evaluations to find the cause of errors by holding meetings and coordinating with teachers at school (interview from informant II).

Name of Informant: BK, Age: 44 Years: Occupation: School leader (Question: How do you overcome challenges in developing learning systems in your school? Answer: I have a meeting with teachers at school, to find solutions, if there are obstacles in the development of learning systems at school (Interview from informant III).

Name of Informant: MD: Age: 51 years: Occupation: School leader (Question: How do you overcome the challenges in developing learning systems in your school? Answer: We coordinate with the teacher, to improve the parts that do not work in the school program/curriculum, this is important to improve the quality of our school! (interview from informant IV).

Name of Informant: PD: Age: 52 years: Occupation: School leader (Question: How do you overcome the challenges in developing a learning system in your school? Answer: Me and the teacher at the school will hold a meeting / coordination to find out the causes of some malfunctioning school programs , and we immediately/look for the problem as a whole! (Interview from informant V).

Name of Informant: UR: Age: 47 years: Occupation: School leader (Question: How do you overcome the challenges in developing a learning system in your school? Answer: Me and the teacher at the school investigate the causes of failure/deficiency, maybe on the program track in developing learning system, and we will apply the results of this innovation, and also re-evaluate the results (Interview from informant VI). 
From the interviews it can be seen that coordination between school leaders and teachers as the closest working partner in handling cases in developing learning systems is indeed very necessary, therefore school leaders must be able to become professional leaders in managing school management. If leadership management in schools runs well, management of education/learning in schools will also run normally and the impact is that the learning system in schools will experience a significant increase. Those are the results of interviews and questionnaire answers that have been analyzed by researchers into narrative form, from this result we can see that the answers of school leaders are almost the same in facing challenges and obstacles in developing learning systems in each school.

In addition to having good managerial skills, a school principal must also have the passion/soul as scientists/researchers, so that he has the ability to produce brilliant ideas, which can be applied to his institution, especially in the field of knowledge that is in line with the curriculum being implemented. From the results of the analysis, interviews and the results of questionnaire answers from participants, it can be seen that the importance of cooperation, coordination, between leaders and teachers in schools, then also researchers see that, teachers as implementing objects in learning development programs must be able to follow developments and progress in transforming sources learning (basically the teacher must also be able to balance progress in developing learning resources).

Programs in schools cannot run well if teachers as 'implementers' in the development of learning systems have not been able to balance the changing times and scientific advances in the provision of knowledge/teaching areas for which they are responsible. This research has produced steps taken if there are challenges in the development of instructional media, and from the results, researchers recommend to be retested in other schools. If the teacher learns throughout his life, it will not be difficult if the teacher gets the task in developing learning resources even though he has to use media/multimedia, or who use technology (Internet, Computers, Software, etc.)

\section{CONCLUSSION}

This study about the challenges/obstacles of a school leader in developing learning systems in schools, from observations, analysis results, then learning outcomes from reference references, as a comparison material about research that has been done, then the results of research analysis using qualitative approaches, case study models. In this study there were eight school leaders as participants and then six people were asked to become informants (still included in the qualitative research criteria). The purpose of this study is to find a solution if there are challenges or obstacles in developing learning systems in school institutions.

This research produces six aspects that need to be done if there are challenges/obstacles in the development of learning systems in schools, including: Coopration,Coordination investigation, analysis. Implementation and evaluation of these aspects have been explained in the results (findings). The role of leadership is clearly very important in the development of learning systems because leaders are as policy makers in schools and leadership in school management, because poor management in one institution/school institution will have an impact on other systems including the learning system, so the role of school leaders is very important for progress the institution he leads.

The role of the teacher is also important in developing the learning system in schools, the teacher is the closest partner of the school leadership in managing the school, and the teacher is the policy maker in the classroom, and the policy is the result of coopration,coordination,consulidation, investigation, analysis and evaluation, and will not run smoothly if the teacher cannot implement it (due to limited knowledge/skills), for that the teacher also needs to improve their knowledge/skills in teaching and in the learning process which is their responsibility in class.

This study presents several criteria from the main problem analysis results, and the results of this study can be used for all levels of schools, from elementary school ,to higher education. Other researchers are invited to explore the results of this research more comprehensively, because good research is research that can be repeated and continue to find new things (novelty), for the benefit of humanity.

\section{ACKNOWLEDGEMENTS}

The researcher would like to thanks the Research and Development Unit (LPPM) of the Kutai Kartanegara University, also to Mr .Heru Suprapto (Head of LPPM Kutaikartanegara University), for his support, so that this research can be completed. 


\section{REFERENCES}

[1] S. H. Davis and L. Darling-Hammond, "Innovative principal preparation programs: what works and how we know," Plan. Chang., vol. 44, no. 1, pp. 25-45, 2012.

[2] G. A. Aarons, "Transformational and transactional leadership: association with attitudes toward evidence-based practice," Psychiatr. Serv., vol. 57, no. 8, pp. 1162-1169, 2006.

[3] A. Woolfolk Hoy, "Educational psychology in teacher education," Educational Psychologist., vol. 35, no. 4, pp. 257-270, 2000.

[4] R. T. Vecaldo, "Instructional leadership beliefs of filipino pre-service teachers," Int. J. Eval. Res. Educ., vol. 8, no. 4, pp. 596-603, 2019.

[5] A. E. Nir, "School-based management and its effect on teacher commitment," Int. J. Leadersh. Educ., vol. 5, no. 4 pp. 323-341, 2002.

[6] J. B. Bigg, Student approaches to learning and studying. Research Monograph, Hawthorn: Australian Council for Educational Research, 1987.

[7] Paul J. Hu, Patrick Y.K. Chau, Olivia R. Liu Sheng, and Kar Yan Tam, "Examining the Technology Acceptance Model Using Physician Acceptance of Telemedicine Technology," J. Manag. Inf. Syst., vol. 16, no. 2, pp 91-122, 2016.

[8] Barret Catharine and Breyer Robert, "The Influence of effective leadership on teaching and learning," Journal of Research Initiatives, vol. 1, no. 2, pp. 1-11, 2014.

[9] D. Wiezorek and C. Manard, "Instructional leadership challenges and practices of novice principals in rural schools," J. Res. Rural Educ., vol. 34, no. 2, pp. 1-21, 2018.

[10] K. Lowery, M. Quick, L. Boyland, R. L. Geesa, and R. Mayes, "It wasn't mentioned and should have been: principals' preparation to support comprehensive school counseling," J. Organ. Educ. Leadersh, vol. 3, no. 2, pp. 1-30, 2018.

[11] V. M. J. Robinson, C. A. Lloyd, and K. J. Rowe, "The impact of leadership on student outcomes: An analysis of the differential effects of leadership types," Educ. Adm. Q., vol. 44, no. 5, pp. 635-674, 2008.

[12] A. L. Terosky and M. Reitano, "Putting followers first: the role of servant leadership in cases of urban, public school principals," J. Sch. Leadersh., vol. 26, no. 2, pp. 192-222, 2016.

[13] O. Abdulrasheed, M. A. Nyako, A. S. Bello, and F. Joda, "Analysis of lecturers on factors affecting quality of training in teacher education," J. Soc. Sci. Res., vol. 2, no. 12, pp. 195-198, 2016.

[14] V. Theodosiou and Y. Karagiorgi, "Primary school heads' professional socialization and leadership development in Cyprus," Int. J. Leadersh. Educ., vol. 20, no. 6, pp. 661-681, 2017.

[15] A.-T. Dina, "Challenges faced by educational leadership on influencing student learning," Procedia - Soc. Behav. Sci., vol. 93, pp. 290-295, Oct 2013.

[16] S. Purwanti, "The role of the principal's leadership in improving the discipline of teachers and staff in Bakti Sejahtera high school, Kongbeng District, East Kutai Regency (in Bahasa)," eJournal Adm. Negara, vol. 1, no. 1, pp. 210-224, 2013.

[17] A. Page and M. Jones, "Rethinking teacher education for classroom behaviour management: Investigation of an alternative model using an online professional experience in an Australian University," Aust. J. Teach. Educ., vol. 43, no. 11, pp. 84-104, 2018.

[18] R. J. Whittle, et al, "The 'perfect' senior (VCE) secondary physical education teacher: Student perceptions of teacher-related factors that influence academic performance," Aust. J. Teach. Educ., vol. 40, no. 8, pp. 1-23, 2015.

[19] J. L. Berger, C. Girardet, C. Vaudroz, and M. Crahay, "Teaching experience, teachers' beliefs, and self-reported classroom management practices: a coherent network," SAGE Open, vol. 8, no. 1, pp. 1-12, 2018.

[20] D. Ho and M. Lee, "Capacity building for school development: current problems and future challenges," Sch. Leadersh. Manag., vol. 36, no. 5, pp. 493-507, 2016.

[21] Taufik, Ali, Tatang. A, Suid Saidi and Zen, "Parental Perspectives on the Excellence of Computer Learning Media in Early Childhood Education," Jurnal Pendidikan Usia Dini, vol. 13, no. November, pp. 356-370, 2019.

[22] C. A. Mullen and R. J. Jones, "Teacher leadership capacity-building: Developing democratically accountable leaders in schools," Teach. Dev., vol. 12, no. 4, pp. 329-340, 2008.

[23] T. Bush and D. Glover, "School leadership models: What do we know?" School Leadership and Management, vol. 34 , no. 5, pp. 553-571, 2014.

[24] T. Trilaksono, et al, "Leadership change design: A professional learning community (PLC) project in eastern Indonesia," Int. J. Eval. Res. Educ., vol. 8, no. 1, pp. 47-56, 2019.

[25] A. Harris, "Teacher Leadership," in International Encyclopedia of the Social \& Behavioral Sciences: Second Edition, Published by Human Resource Management Academic Research Society, 2015.

[26] B. Vanblaere and G. Devos, "Relating school leadership to perceived professional learning community characteristics: A multilevel analysis," Teach. Teach. Educ., vol. 57, no. 2, pp. 26-38, 2016.

[27] M. Coelli and D. A. Green, "Leadership effects: School principals and student outcomes," Econ. Educ. Rev., vol. 31, no. 1, pp. 92-109, 2012.

[28] O. Eyal and G. Roth, "Principals' leadership and teachers' motivation: Self-determination theory analysis," J. Educ. Adm., vol. 49, no. 3, pp. 256-27, 2011.

[29] J. W. Creswell, Qualitative inquiry and research design: Choosing among five traditions, CA: Sage,1998.

[30] M. B. Milles, M. A. Huberman, and J. Saldana, Qualitative data analysis a methods sourcebook Edition 3. Thousand Oaks, Califorinia: SAGE Publications, Inc., 2014.

[31] R. K. Yin, Applications of case study research, Appl. Soc. Res. Methods Ser., (Third ed). SAGE Publications, 2002. 